\title{
Developing a Conceptual Model of Marine Farming in NZ
}

\author{
Hamish G. Rennie, Roger White, Lars Brabyn
}

\begin{abstract}
Survey and GIS data analysis describes the relative influence of biophysical and human variables on site choices made by marine farmers in New Zealand.

Community conflicts have grown in importance in determining farm location and different government planning strategies leave distinct signature patterns. Recent legislation empowers local governments to choose among three strategies for future regional aquaculture development. This paper suggests each strategy could result in different spatial outcomes. Simulation modelling of the type described here can provide a better understanding of farmer responses to management approaches and the range of futures that could result from planning choices made today.
\end{abstract}

\section{Introduction}

The recent upsurge in marine spatial planning has elevated interest in solving conflicts between different users of marine 'commons'. As a means for (sustainable) development, providing potential employment and earning opportunities for less developed countries or regions, the expansion of marine farming ${ }^{1}$ has been hailed as a 'blue revolution', necessary to meet the increasing demand for fish. However, it also contributes to conflicts over marine space and in many places has become a locally significant user of marine space. The need for integrated impact assessment methods and ex ante models that include the human dimension is well recognised in land and water resource management [1], but less so in marine farming. The potential for using agent based modelling in coastal decision-support systems has been identified in a recent review of such tools [2].

This paper presents empirical evidence on factors that influence the spatial development of New Zealand's marine farming sector prior to the 2002 implementation of a national moratorium. An examination of the spatial outcomes of the pre-moratorium planning regimes yields a conceptual model that indicates differing future spatial expressions of marine farming under new alternative planning strategies. This suggests the utility of a Geographic Information System (GIS) combined with an individual based model for simulating future marine farming development to assist regional authorities choose between strategies. The model is

\footnotetext{
${ }^{1}$ For the purposes of this paper marine farming in the New Zealand context means the breeding, hatching, cultivating, rearing, or ongrowing of fish, aquatic life, or seaweed for harvest if this involves the occupation of a space in the area between mean high water at spring tides and the 12 nautical mile boundary of the territorial sea. It does not include relaying or releasing of (shell)fish into uncontrolled sea space (i.e., it does not include enhancement of fisheries). The species farmed must be in the exclusive and continuous possession or control (i.e, within a cage) of the person undertaking the activity; or able to be distinguished or kept separate from naturally occurring species. Some activities and species (e.g., marine mammals) that might be considered marine farming in earlier or other contexts are excluded by this definition which essentially paraphrases current New Zealand law.
} 
constrained to a conceptualisation at this stage as the data required to implement it is not available and no programme for collection exists. To that end the model indicates the nature of data that policy evaluators should be collecting to assess their options.

\section{The framework for marine farming in New Zealand}

It has been argued that Maori established marine farming in New Zealand several hundred years ago [3] and legislation formally enabling marine farming has existed since 1866 [4]. However, it was not until the 1960s that legislative changes enabled wide spread expansion and commercialisation of marine farming activity. This expansion has been mainly with mussels, oysters, and salmon, but there has also been consideration of other species ranging from seaweeds and sponges to other finfish species. The allocation of rights to occupy space for marine farming has varied significantly in administrative responsibilities and legal mechanisms (see [4] for a comprehensive review), but essentially has featured an ongoing tension between management of fisheries issues (e.g., poaching and pests) under fisheries legislation and the allocation of space and regulation of effects (e.g., impacts on navigation) under other legislation [5], [6]. This has been complicated by the introduction in the 1970s of marine protected area legislation and, in the 1980s, by spatial rights for commercial fishers through the Quota Management System [7], [8]. Since the 1970s, local government has played an increased role in the regulatory aspects and the Resource Management Act 1991 (RMA) made regional governments the primary regulatory role for non-fisheries issues.

The most significant changes from the 1960s to 2002 were the changes in approach to planning. Initially marine farms were created on a case by case basis through either a centrally administered lease or licence system. Central government marine farm plans identifying where farms could or could not go were introduced in the late 1960s to facilitate the resolution of conflicts between different users of sea space. Other central government agencies concurrently developed non-statutory plans to guide the protection of seascapes, terrestrial reserves and navigation. Since the 1970s, local authorities have responded to the devolution of land and marine use planning responsibilities (excluding fisheries) by developing plans, some of which affected marine farming [9], [5]. All these plans, coupled with significant internal central government fisheries policies, have significantly shaped the development of the industry [4].

Before 1991, the plans took the form of regulating the activity of marine farming and often specifically identified areas that it could occur in and concurrently prohibited it from others. By contrast the RMA is legislation designed to be applied to a wide range of resource management issues, and has a basic principle of sustainability, a method of effects based planning, and implement governance at a local level. In theory, effects based planning ensures that plans and zones are based on environmental effects rather than an activity. Although the emphasis of the RMA is on the natural and physical environment, social and cultural effects are also included. Local authorities (elected councils) provide plans that show what effects are allowed and what effects are discretionary and require consent. Thus local authorities should not have rules that prohibit marine farming, but could have rules that prohibit specific 
effects such as restricting navigation, creating visual disamenities or discharging substances into the sea. In combination these restrictions on effects might effectively prevent marine farming in a particular area. However, the focus on effects also provided an incentive for potential farmers to invest in technology, methods or species that could address their adverse effects (e.g., through using open ocean or submerged farms).

Primarily to ensure that there is national consistency across local authority boundaries and that national interests are addressed, the RMA allows for national policy statements to be developed by central government. Local authorities must give effect to these. This includes a mandatory national coastal policy statement administered by the Department of Conservation ${ }^{2}$. Separate assessments of the effects of farms on fisheries are required by the Ministry of Fisheries, but the criteria against which these assessments are to be undertaken and the timeframes for their processing remain illdefined. There is also little provision for public participation or specific rights of appeal against the Ministry's decisions.

In summary, to obtain permission to establish a marine farm under the RMA it must be demonstrated that the effects of the activity are sustainable and do not exceed specified environmental thresholds. In reality this involves an impact assessment report that includes a wide range of (non-fishing) biophysical and social factors, and considerable capacity has been built into the legislation's processes for public participation, including rights of appeal to a specialised Environment Court. The implications of these factors are described in the later section of this paper that shows the results of an empirical investigation on determinants of marine farm distribution in New Zealand.

Heightened political tensions over claims by Maori to ownership of foreshore and seabed, coupled with conflicts between fishers (especially commercial), boaters and adjacent land users on one side and marine farmers on the other, resulted in the 2002 imposition of a national moratorium on all new applications for aquaculture space. Subsequent amendments to the RMA have enabled regional councils to include provision for areas to be zoned as Aquaculture Management Areas (AMAs) in their regional coastal plans. All existing marine farms are deemed to be AMAs until 2025. Any new farms can only be developed in AMAs. New AMAs can be created by changing regional coastal plans through a specified public process initiated by the regional council (CIPC) or by individuals. In the latter case individuals can initiate an uninvited private plan change (UPPC). Alternatively, they may respond to publicly notified invitations from the councils (IPPC). The CIPC strategy involves the local authority identifying areas where marine farming can occur. Regardless of the type of plan change, each has to go through a transparent, public, appealable process during which opposition is likely from many directions.

The mechanism for allocating space within a new AMA to individual farmers can vary. Unless otherwise specified in its plan, the default mechanism for CIPC and UPPC is public tendering. The IPPC process, however, enables the council to allocate the AMA to the person who successfully responded to the invitation to propose a plan change. The UPPC, by contrast, involves a potential farmer(s) applying for a plan

\footnotetext{
${ }^{2}$ The Department of Conservation is equivalent to a Ministry and has its own Minister.
} 
change. If the plan change is approved the local authority then allocates the space within the AMA according to whatever process it has decided in its plan or to tender it. This means that those who proposed the UPPC might not get any or much of the space in the AMA. This disincentive for potential farmers is expected to deter those regional councils who want growth in marine farming from relying on the UPPC strategy.

The AMA system differs from the pre-moratorium system in that the focus has moved to the activity of marine farming. The processes for deciding where an AMA zone might be inserted into a regional coastal plan are not well defined and largely discretionary with regard to the non-fisheries aspects. However, once an area has been identified it must be primarily used for aquaculture and the Ministry of Fisheries must assess whether there will be undue adverse effects on customary, recreational, or commercial fisheries. The outcome of the Ministry's assessment may be a reduction in the area of the AMA or a reservation over part of the area until prospective farmers have obtained agreement from quota holders to proceed; effectively providing a right of veto for quota holders (see [6] for a discussion of equity issues).

By the end of 2007, only deemed AMAs existed. No AMAs had been created using the new provisions and there was no consistency in the choice of strategy being pursued by different local authorities. There were also no robust assessments of the probable or possible cumulative spatial consequences of the strategies being explored.

\section{Variables for choosing spatial location}

To anticipate future spatial patterns of development it is necessary to understand the variables that affect the spatial choices of marine farmers (the 'site-seekers'). This also enables the development of simulation models to aid policy makers in visualising the range of potential spatial outcomes of different strategies to create AMAs. Such simulation forms part and parcel of the transparent ex ante integrated impact assessment of cumulative effects sought by policy makers [10], [1].

A late 1990s review of international literature identified approximately twenty-five variables that affect decisions on where to have marine farms (Table 1) [4].

\section{Insert Table 1 Variables affecting decisions on locations of marine farms (from [4])}

Subsequent publications have not expanded on these, but have focussed on the local milieu, individual strategies in response to aquaculture development and conflicts with other users [74], [75], [76], [77].

Although the variables have been categorised as biophysical and socio-cultural, it is difficult to consider them independently because of the multi-directional interactions among them. Intuitively, some factors are more fundamental to marine farming than others. For instance, the life-supporting capacity of the environment is essential and 'water quality' is generally considered fundamental. However, such assumptions should not be uncritically examined. For instance, some species are naturally more tolerant to different environmental parameters than others, and this tolerance may 
vary for a species at different stages of its life cycle (e.g., tolerance for salinity or temperature at spawning may differ from that during growth stages). Water quality that is not suitable for some species may be acceptable, indeed necessary for others. Water quality may be significant for the end use of the species harvested, but not all species necessarily need to be harvested for human consumption. Biopharmaceutical, aquaria and ornamental uses may mean that water quality may not need to be as stringent a constraint as it might be when used to produce fish for consumption. Lower quality water can be used for growing species than is used for depuration. The availability of depuration water enables farming practices that use growing water that otherwise might not be of sufficient quality for marine farming.

When biophysical variables are identified in the literature, they are usually in the context of some assumed standard form of technology and farming practice (e.g., surface finfish farming). The literature traditionally rates 'sheltered water' highly (e.g., [11], [14], [16], [18], [20], [22]), however, recent developments in open water farming [77] suggest that this is no longer as important. The relative importance of the variables is therefore dependent on the species, methods and technology used. The combination of technology, methods, and socio-cultural and biophysical variables will affect the cost (financial or otherwise) for the farmer. This can be offset by markets and marketing strategies. The extent to which the various variables constrain the evolution of marine farming depends on the available technology and capital (social and financial) to overcome natural and socio-cultural constraints. Identifying some variables as more important than others must be done within their socio-cultural and biophysical contexts.

The capacity and preparedness to use particular combinations of methods, technologies and species will depend on the motivation of individuals in the private and public sectors, and their motivations might be quite varied [78]. Different personality traits and ideological positions may influence views of what is socially acceptable within a pluralist society. Some 'entrepreneurial pioneers' are likely to adopt higher risk, more resource demanding positions than would more conservative would-be farmers or non-local, perhaps urban, investors. The set of criteria that each might consider important in determining their preferred site would therefore be expected to differ also.

Regulatory regimes may incorporate a number of different approaches to the development of marine farming and these too depend on individual assumptions and perceptions of the nature of the 'standard' farming activities and their effects as well as wider societal goals and ideologies. The consequences for the development of marine farming, both over time and in terms of its spatial outcomes, have been assessed and a model of the possible development of the industry under different scenarios postulated for New Zealand [4]. Here we summarise the key variables and develop a more formalised conceptual model as the basis for future work on simulating aquaculture development in New Zealand.

\section{Method}


The development of the model is based on Rennie [4] and subsequent analyses of New Zealand case law, government policy and legislation, and experiential participant observation. In summary, Rennie [4] developed a GIS-linked database of marine farm rights to occupy marine space and compared the resultant spatial distribution and pattern of development at national regional and local (individual bay) levels with relevant planning maps and policies. Relevant government administrators and industry representatives were interviewed. He also undertook a postal questionnaire survey of the population of New Zealand marine farmers in two groups; those owning the rights to farm one site (single-site owners) and those owning the right to harvest two to ten sites (multi-site owners). The small number of owners of more than ten sites and limitations in designing a practicable questionnaire meant that representatives of those who owned more than ten sites were personally interviewed instead of being included in the postal survey. Interview data from these owners highlighted significant differences in corporate strategies that made specifically including them in the results as a distinct group of little assistance. Their views were largely in accord with those of the 2-10 site owners and many of their farms had been acquired through purchase of existing farms. With occasional exceptions, they played a limited role in the spread of marine farms and changes in ownership patterns are not the prime focus of this paper.

Determining a response rate and rigorously maintaining the separate categories was difficult due to the nature of ownership arrangements (especially where partnerships were involved) and the methods used by the Ministry of Fisheries in recording site ownership and allocating "client" numbers (see [4] for a full discussion). Based on more than fifteen years' involvement with the industry, the results are considered reasonably robust.

The postal survey data was analysed using chi-squared, cluster and latent factor analyses [4]. A detailed analysis of statutory provisions for marine farming in New Zealand, related planning and policy documents and institutions was augmented by the analysis of key case law [4]. Results relevant to the development of the conceptual model are presented here and further refined by analysis of subsequent cases, statutory developments [79], [80], [6], regional coastal plans and participant observation of material presented at the first local authority hearing of a proposed regional coastal plan change relating to AMAs (public hearings held by Northland Regional Council (NRC), $25^{\text {th }}$ November to $4^{\text {th }}$ December 2007).

\section{Observable Spatial Relationships}

The GIS data showed some clear physiographical parameters affecting the location of marine farms. For instance, initially there was a tendency for farms to align with shorelines or harbour channels. Infilling, subdivision and intensified use of some spaces set aside for marine farming occurred. In the 1990s new farms, or extensions to existing farms, continued to be established in inner areas, concurrent with the emergence of large, open water farm blocks. Older farms were in sheltered bays, but by the 1990 s more exposed sites were sought. Since 2000, rights to establish farms of over 2,000ha have been gained in oceanic water more than $10 \mathrm{~km}$ off the eastern shores of New Zealand. Although these are open water, offshore sites, they are 
sheltered from the prevailing westerly swells by the main islands of New Zealand. There have yet to be substantial offshore farms proposed to the west of the country. Therefore, sheltered water appears to remain important, but perhaps needs to be considered at a more grand scale than traditionally. The weight given to 'shelter' needs to be rethought accordingly.

Places of concentrated development, perhaps to achieve economies of scale, and some areas of scattered, perhaps exploratory, sites were identifiable. Some of these patterns of development can be explained by the planning regimes in place at the time of their establishment, but other plans simply continued and extended the patterns of already established farm development. There are also many examples of places where plans allowed farms, but none eventuated.

The survey data of marine farm owners' perceptions of locations and their rationale for obtaining particular sites provided some insights into the discrepancies observed.

\section{Variables Affecting the Individual Site-Seekers}

The survey results revealed some significant differences between types of marine farmers. Single-owner respondents were predominantly male, aged over fifty and with no specialised training or qualification relevant to marine farming, but with an average of about 14 years experience. In contrast, the multi-owner respondents were almost all male, significantly younger, with a similar number of years experience, but with a higher proportion of formally trained/qualified respondents. However, few of either category of questionnaire respondents had relevant specialist qualifications. The most frequently mentioned qualification was 'commercial boat/launch master certificate' - essentially a marine equivalent of a terrestrial farmer's 'heavy traffic' (i.e., 'truck') driver's licence. There was a general trend for single-owners to have started farming at an older age than their equivalent multi- farm owners. The proportion of Maori respondents was similar to that of Maori in the general population, but slightly higher among the multi-owners $(13.6 \%)$ than among the single owners $(12 \%)$. A higher percentage of single-owner respondents saw their farms as hobby/lifestyle or hapu/iwi ${ }^{3}$-owned farms compared to the multi-owners. The single-owners were predominantly land farmers or, secondly, fishers before becoming involved in marine farming. Among multi-owners, land farming was also the most frequently recorded background, closely followed by 'marine farming' and 'marine science'.

\footnotetext{
${ }^{3}$ Iwi and hapu are effectively 'tribe' and 'extended family' respectively. A single owner relates to the number of farms sites recorded as owned by that 'client' on the Ministry of Fisheries register. Thus a single owner may mean that one tribe or one family or one company is recorded as owning only one farm. Another company or tribe might own several farms (i.e., be a multi owner). A tribe comprises many members, so the one farm owned by the tribe has many individuals who have a share in ownership of it. The survey responses are taken as representative of the view of the tribe or company, as expressed by the person with authority to speak for the many owners of the single or multiple farms owned.
} 
There were also geographical variations. More multi-farm than single farm respondents were present in Marlborough and Northland, but single-owners predominate among respondents from most other regions. Maori respondents were predominantly in Northland and Marlborough and showed no apparent regional differences in number of farms owned. With the exception of the Marlborough respondents, the majority of owners saw their farm as an owner-operated business and, less often, as a family-owned business. The single-owners show a similar, but less pronounced, pattern.

Many farms initially started with one approved species and subsequently gained approval for additional species (most often to expand the nature of their 'existing rights' in anticipation of changes in legislation). The relationship between species and previous employment was examined using the species first approved for a farm as the key species for each farm. Previous employment was recoded into four categories: fishing, farming on land, marine farming, and 'other'. The combined category of 'other' employment was clearly the dominant background for both mussels and rock oysters ${ }^{4}$. However, there was such diversity within the 'other' category of previous employment that no single occupational group could be identified that was of similar scale to the three main backgrounds.

The mussel and oyster farmers differed significantly in the previous employment of their owners. A higher proportion of the mussel group respondents had fishing as their previous employment when compared to employment of the oyster group. Farming on land was by far the most commonly reported form of previous employment for the mussel dominated Marlborough region, but marine farming was the dominant category in both oyster-dominated regions, Northland and Auckland. The results strongly support anecdotal evidence that oyster farmers are predominantly from farming backgrounds, but this must now be extended to include marine as well as terrestrial farming.

There was considerable agreement between respondents on the importance or otherwise of particular variables affecting their choice of location. Water quality was, for instance, generally considered very or critically important. There were, however, marked regional differences in the views on the importance of some variables and the relative importance of some variables changed over time. There were also distinct differences between owners of single farm sites and those who owned several sites.

The multi-owners gave all of their variables, on average, higher ratings of importance than did the single-owners (Table 2). The most obvious difference in the order of ranking of the variables rated as most important was that the multi-owners rated proximity to 'sources of spat/seed/fingerlings/smolt' as more important than sheltered water when they obtained their first site. They also did not consider planning restrictions as important as did the single-owners (Table 3). Both sets of owners gave higher ratings of importance to the support/opposition from the local community in

\footnotetext{
${ }^{4}$ Mussels are the Green lipped variety (Perna caniculus), Rock oysters (Crassostrea glomerata) are farmed, but of much less importance than the predominant exotic Pacific oyster (Crassostrea gigas). Salmon (Oncorhynchus tshawytscha) is also farmed, but of much less spatial importance.
} 
2000 than when they first started farming, and planning restrictions had moved to second most important variable overall. This suggests the more participatory nature of the RMA has affected the ease of gaining a farm site. Both single and multi-farm owners also gave the 'proximity of the site to home' a lower rating in 2000 than when they had first obtained a farm site. Although shelter remained important for singleowners, the multi-owners dropped it to lower than both community and iwi/hapu support/opposition.

\section{Insert Table 2 Average rating of variables' importance in determining where to buy or establish a marine farm site}

\section{Insert Table 3 Most critical variables for obtaining site}

In summary, as anticipated from the literature reviewed, all the variables were of some, but varying, importance. There were, however, regional distinctions and differences between single-owners and multi-owners. Clearly, water quality is of most importance, but sheltered water has become much less significant over the years. Planning and community views, including each of the separate community groups (iwi, recreational and commercial), have increased in significance. Access has a surprisingly low relative importance for both groups, but is still of at least moderate importance.

The more frequent and wider exposure of the multi-owners to the processes of obtaining a site may have resulted in their developing the view that all the factors are of at least moderate importance. The advent of the RMA and its requirements for fuller environmental impact assessments than were necessary under previous regimes appeared partly responsible for this. Clearly, variables that might be considered indicative of using marine farming as a means of development of rural areas and providing employment for local youth are considered relatively unimportant, as is government support or encouragement.

The higher ranking that single-owners gave to government support/encouragement may reflect increased costs of obtaining sites. For instance, the heightened level of iwi involvement and the planning requirements may have increased application costs. Consequently they see some form of support (e.g., a subsidy) from government as important.

Hierarchical clustering of the responses for when sites were first obtained ('original' classification), led to a three-cluster solution. Repeating the process for the year 2000 showed some interesting changes (Table 4). A two-cluster solution was most appropriate for the 2000 classification, but to make comparisons easier a three cluster approach was used [4]. In a two-cluster solution for the 2000 classification the first ('Community') and second ('Economic') clusters combine (light shading in Table 4).

\section{Insert Table 4 Clustering of similar variables that affected decisions on farm sites}

Respondents would have been affected by the socio-cultural context at the time that they first obtained their sites. As this occurred at different times the contexts may have been quite varied. This may affect the 'original' classification and it is therefore 
less robust than the '2000' classification. For this reason there has been no attempt to name the 'original' clusters.

The clusters were relatively stable, but the movement of 'community support/opposition' into the same cluster as the other 'support/opposition' variables created an overall 'community' cluster in the year 2000. Shelter, water quality and planning restrictions comprised the 'fundamental' necessities for a viable marine farm. The remaining group could essentially be described as an 'economic' cluster, with Government support being seen in terms of cost-cutting.

A principal axis factor analysis was carried out for the variables assumed to have some importance in location decisions. Rotations were employed to reveal a fourfactor solution accounting for $53 \%$ of the variance in the responses relating to the year 2000 (Figure 1) ${ }^{5}$.

\section{Insert Figure 1 Factors influencing importance of locational variables in 2000}

Iwi/hapu support or opposition was a complex variable in 2000, but was split between the conflict level and community factors. It may be that in 2000 the community factor related to more formal control of the planning process, whereas the conflict level factor represented sub-community relationships. The variables are not truly independent in that the community variable could include elements of iwi/hapu, recreational and commercial fishers.

The 'fundamentals' factor and the 'economic' factor are less distinct in the factor analysis than in the cluster analysis and have been relabelled 'bioeconomic fundamentals'.

There was little variation between farmers in the different regions in their responses regarding variables determining site desirability. There were, however, some distinct differences between the responses of single-owners and those of multi-owners. The latter's averaged rating of all features as 'desirable', contrasted markedly with the single-owners' averaged rating of most features as 'undesirable' (Table 5).

\section{Insert Table 5 Average rating of desirability of variables for site selection}

The two groups shared a desire for isolated rurality, but whereas being near a river was one of the most desirable site characteristics for multi-owners it was consistently among the least desirable for single-owners (Tables 6 and 7). There was no obvious reason for this dichotomy and interviews did not shed any light. The preference for remote or isolated areas clearly reflected a desire to avoid conflict with other users and this was supported by comments to the effect that it was hard to obtain sites near areas of high natural character because of conflict with conservation interests. These conflicts outweighed the advantage of higher water quality and other desirable

\footnotetext{
${ }^{5}$ Both varimax and oblimin rotations were performed with little difference between the results. The Kaiser-Meyer-Olkin Measure of Sampling Adequacy $(0.8+)$ and the Bartlett Test of Sphericity (.000) were quite favourable.
} 
biophysical characteristics of natural areas. Such conflicts were less where the remote site was adjacent to terrestrial farmland, a similar socio-cultural milieu of primary production.

Insert Table 6 Most desirable site characteristics (i.e., score at least less than 3)

Insert Table 7 Least desirable site characteristics (i.e., score at least more than 3)

There was little or no change in the relative average ratings of desirability of the different site characteristics between first obtaining a site and choosing a site in 2000. All factors, except being isolated or near farmland (which did not change their rating), increased their level of undesirability for single-owners. In contrast, all factors, except avoiding urban areas, became relatively more desirable for the multi-owners.

Interestingly, cluster analysis indicated that by 2000, farmland was no longer considered any more desirable than other forms of adjacent land use. Sites near urban areas were, however, less desirable by 2000 , suggesting perhaps a greater concern with competition from urban water uses (e.g., recreation and waste disposal).

There was a clearly entrepreneurial site-developer group present in the period since the passing of the RMA. Such entrepreneurial actors would partner with large integrated fishing processors and iwi to effectively remove the two primary conflicting objectors with strong property right claims under fisheries legislation. They would also propose technology and sites that they considered would be able to meet the requirements of the RMA. Large companies owning more than 10 sites have also adopted strategies to purchase existing sites and develop a range of other sites, including extremely large off shore areas and using technologies that minimise their impacts (e.g., submerged mussel farms). The variance within and between such players confirms the need to consider the capacities, backgrounds, motivations and decision-making strategies of individual companies and owners in anticipating the future spatial expansion and form of marine farming.

\section{Management factors}

Rennie's [4] analysis of New Zealand's policies, plans, institutions and spatial outcomes concluded that there were particular spatial signatures associated with different approaches to plans and related political or institutional ideology (Table 8).

\section{Insert Table 8 Characteristic signature patterns under different regulatory era and planning approaches}

For instance, the modern era featured restrictive approaches with rules in plans defining where farming was prohibited and, by default, identifying areas where it was allowed. The resultant pattern reflected a state preference for concentration to achieve economies of scale, an industrial type of farming. This had clear negative implications for other types of and motivations for farming and may well have had implications for long term sustainability and sector vulnerability. 
By contrast the 'transitional' RMA period enabled considerable diversity of farm types, practices and species. It encouraged experimentation and internalisation of environmental effects. Its major problem lay in the 'transitional' dual permitting system (requiring a permit from the Ministry of Fisheries as well as from the regional councils) that meant delays, uncertainties and tensions between the fishing and aquaculture sectors. The lack of operative plans prepared under the new RMA regime also contributed to the litigious nature of the RMA regime as the various competing actors fought over multi-use marine commons [9], [4]. The last row in Table 8 represents Rennie's [4] speculations on the then anticipated post-moratorium regime.

The post-moratorium era effectively commenced in 2005 with the passage of several legislative amendments to enable regional councils to remove the moratorium if they so desired. The legislation defined four options for planning to enable marine aquaculture. Three of these strategies (IPPC, UPPC, CIPC) enable the creation of new AMAs, the fourth, a 'no new AMA' strategy, should ultimately reduce the number of AMAs unless or until one of the previous three is chosen. Which strategy is adopted is dependent on the specific regional local authority's attitude to the future of aquaculture, but the choice may provide spatial outcomes that are similar to those of previous regimes. These new planning mechanisms have yet to be fully implemented by any regional council. However, although the range of options was not fully anticipated by Rennie's [4] speculations on the post-moratorium era, history suggests a probable set of signature patterns (Table 9).

\section{Insert Table 9 Probable post-moratorium planning regime signature patterns}

Initial indications (as at the end of 2007) are that while some regional councils (e.g., Northland) see further aquaculture development as significant for enabling people and communities in their region to enhance social and economic well-being, others do not (e.g., Canterbury, West Coast). The strategies consequently vary between councils, but uncertainty of approach has also emerged within at least one regional council.

Northland Regional Council (NRC) initially adopted a collaborative approach with Maori, industry (represented by a consortium of farm owners, including Maori, already active in the region), environmental and community groups. Commencing in 2002, significant progress was made toward a council initiated plan change (CIPC) that would specify particular areas as new AMA. However, in 2007 the Council released a quite different plan change proposal that effectively removed almost all existing restrictions on aquaculture and enabled invited private plan change (IPPC) proposals for most of the region [81]. The collaborative approach would have been much more restrictive, but provided greater certainty than the new approach.

Most submitters to the NRC hearing preferred greater certainty, and frequent reference was made in oral evidence to the desirability of the earlier CIPC strategy. Indeed, the industry saw the IPPC strategy as a return to the post-RMA 'transition' era, with the public opposing a potential proliferation of aquaculture leading to stagnation of the industry [82]. The community, especially those where there were significant potential urban residential developments or private lifestyle and investment farm properties, tended to oppose the proposals. The recreational boating and tourism interests also strongly opposed any approach that enabled consideration of new AMA in sheltered harbours frequented by them. Maori interests generally 
sought provision for both customary non-commercial AMA and commercial AMA in close proximity to their lands. This was in addition to the areas that had been previously agreed through the collaborative approach. It was readily apparent during the hearing that almost all submitters visualised future aquaculture as replicating past aquaculture methods and purposes (i.e., oyster racks and mussel longlines for (commercial) consumption production).

However, the NRC's IPPC strategy had been motivated by the desire to enable aquaculturists to invest in technologies that address potential environmental effects and thereby to allow the development of new (to the region) forms of aquaculture (e.g., finfish farming), new species (e.g., sea horses) and special purpose farms (e.g., for tourism, education or pharmaceutical purposes). As the legislation and policy had been crafted primarily for commercial farming, Maori requests at the hearing for noncommercial farms to enable them to meet customary needs (e.g., food security for ceremonial purposes) created new, unanticipated issues.

The post-2005 experience in Northland therefore comprises a shift from a strategy that was likely to yield a spatial outcome similar to the pre-RMA 'modern' regime, to one that is likely to duplicate the 'transitional' RMA regime. The latter suggests a future with UPPC and IPPC applications for competing and possibly overlapping AMAs; a litigious situation, but one providing much greater diversity in the nature of the spatial and structural outcomes. This potential outcome may be substantially reshaped by the Ministry of Fisheries' 'undue adverse effects on fishing' analyses and compensatory agreements reached with quota holders. The potentially quite diverse range of outcomes of each approach suggests a need for simulation models to aid decision making.

In summary, the analyses reinforce the diverse capacities and motivations of individual site-seekers and management agencies in choosing strategies for creating marine farming space. These strategies and personalities have to be related to the biophysical nature of different settings in a manner that enables the natural dynamism present to be successfully modelled if the cumulative outcomes of the different available management strategies are able to be compared.

\section{Looking Forward: The Advantages of Modeling the Marine Farming System}

Some features considered important by marine farmers are similar to those in other eco-commodity systems (e.g., the importance of water quality), but the prominence of 'community' and 'conflict' factors (suggested in the factor analyses) and the importance of planning restrictions, iwi and commercial fishers' views (identified through questionnaires, plans and court cases) suggest a conceptual model of variables influencing site-seeker behaviour that incorporates these concerns.

Any marine farming management strategy is implicitly based on assumptions about what activities marine farmers will be carrying out, where it is possible to carry them out, where they will seek to carry them out, and what the consequences of those activities in particular areas will be. Furthermore, there is an assumption that the marine farmers and marine farm site-seekers will respond to the management programme in certain ways. However, as we have seen, these assumptions are not always valid. In the pre-RMA period, for example, some areas available for farming 
were never occupied; while in the current period, the NRC's change from a CIPC to an IPCC based approach, on the assumption that the latter management regime would encourage innovative aquaculture operations, has had no such effect. The industry response has been to prefer a traditional, 'modern' approach. Thus a better understanding of the needs and responses of marine farm operators would increase the effectiveness of management strategies. But how can this be achieved?

While the empirical findings from the survey of marine farmers are potentially important for understanding the behaviour of potential operators in searching for marine farm sites, the data are not in themselves sufficient to explain the actual behaviour of marine farm site seekers. Nor, therefore, do they provide a basis for understanding the long term cumulative consequences of various possible management strategies. The empirical findings can in fact be misleading, because the responses given will tend to reflect the context. For example water quality and adjacent land use may to some extent be proxies for each other, so that it is arbitrary which the marine farmer lists as important. Statistical analysis will give a general description of the existing situation, but will not necessarily provide much insight into the processes by which the situation arose, and so is not a good basis for either understanding the current situation or anticipating how it will change in the future.

In this situation, combining a GIS with simulation based modeling of the marine farming system is probably the most promising approach. An individual based model of marine farmers running on a GIS data base of the biophysical and land use factors thought to be important to site location would provide a useful indication of where marine farmers would actually seek space under a variety of circumstances involving adjacent land based activities, other users of the water, and various possible management strategies. Using the model, it would be possible to anticipate some of the possible consequences of changes in management strategies under a variety of scenarios involving industry structure, new technologies, and new types of marine farming.

A model of this type has been developed for the lobster fishery of the west coast of the island of Newfoundland, Canada [83] in co-operation with the Department of Fisheries and Oceans Canada and the National Institute for Coasts and Sea (RIKZ) of the Netherlands. That model can be used to investigate the likely impact of several proposed management innovations in terms of both the total catch and the variability of catch for individual operators, communities, and the industry as a whole. In addition, it serves to alert users to the possibility of unanticipated or counterintuitive phenomena. For example, experiments with the model suggest that when lobster locations are relatively predictable, communication among lobster fishers is likely to reduce total catch. In contrast, when lobster locations are more variable, the extra information, even when some of it is intended to mislead and all of it is at least a day out of date, usually results in an increased take of lobsters.

Individual based modelling is a relatively new technique that is increasingly favoured as a tool for understanding complex adaptive systems [84], [85]. These models can be quite realistic compared to other types, and they are particularly appropriate for modelling human systems, since they permit a direct representation of both the differences among individual people and the complex, context- dependent decision making that people engage in. The collective behaviour of the system emerges as a 
result of the many interconnected decisions and actions taken by the individual agents in the system [86], [87], [88], [89], [90], [91].

In the New Zealand case agents would represent individual marine farm operators, both potential and actual. Each agent would have a number of characteristics such as number of marine farms operated, corporate status, and history of experience. These characteristics are updated as the model runs. The aquaculture environment would be represented in a GIS data base containing information on such factors as water characteristics, biological factors, competing water uses, and adjacent land use and land status. The core model would then simulate the choice of marine farm locations by new and expanding operators on the basis of their evaluation of the relevant factors stored in the GIS database. The agents representing the operators would have imperfect knowledge of the factors in the database, and both the quality of that knowledge and their use of it in site evaluation and choice would depend on their individual characteristics. For example, operators will tend to have better knowledge of the biophysical factors in areas near their existing operations.

Choices generated in the core model would be filtered through a model module representing the operation of the management process, with various possible management regimes represented as distinct scenarios. Under some management scenarios, the process will indeed consist of a simple filtering out of choices that do not conform to regulations. Under others (e.g., the CIPC and the IPCC), the process will be one involving interaction of management agents and various competing agents, including those representing other marine farmers, other water users, and land based interests. A schematic diagram showing the steps and relationships in one iteration of the model is presented in Figure 2.

\section{Insert figure 2 Schematic of an iteration of an individual based model of marine aquaculture site selection}

Since this is a process model, it would simulate the growth and change in marine farm locations over a number of years. Existing operations influence subsequent locations, both directly, through emulation effects (e.g., a terrestrial farmer becomes aware of the possibilities of marine farming through observation of local operations), and indirectly, for example by causing deteriorating water quality. More importantly, anticipatory effects will appear. As the model runs, agents will accumulate experience histories, and will begin to base their actions in part on their past experience. For example, some agents may anticipate delays or difficulties in gaining approval for a new site under an IPCC process and so will not choose this process to acquire a new site, while others will have learned to negotiate the process successfully and so will opt for the IPCC.

A sufficiently realistic model, once implemented, calibrated, and validated, may play a useful supplementary role in formulating or adapting a regulatory framework. But even before that, the model building process itself may prove useful in raising and clarifying issues that may not have been evident before the modeling exercise. Constructing a process model requires that the perception, evaluation, and decision making processes of each type of agent be thought through in detail, given the individual agent characteristics and the various circumstances that can confront the individuals. While the design or analysis of a regulatory process usually focuses on 
the regulatory structure itself, in the case of the model, the focus is on the individuals subject to the regulatory process - on their response to that process given their understanding of it, and given also their knowledge of the natural, economic, and social environments in which they operate. The modeling process itself may therefore lead to a better understanding of the system being modeled.

Data is always an issue. In the case of the model proposed here, basic biophysical, water use, and land use data will be required for the GIS data base which constitutes the foundation on which the model rests. Some of this data is already available, but much is not. As exemplified in the NRC hearing, there is already a demand for more and better data from managers and the public, who complain that they lack sufficient data on which to base the decisions they must make. The modeling process will help to clarify what data is necessary and will buttress the argument for better data.

Beyond the data required for the GIS, however, the demands of the model are modest. Unlike statistical models, which are data-intensive, individual based models require relatively little data in the traditional sense. Specifying agents in a model depends more on an understanding of the real world individuals the agents represent. The model will contain a population of agents of any particular type (e.g., a population of marine farmers), with each agent differing in various ways from others in the population, just as is the case with the population of real individuals. Participant observation is typically among the best ways to get the type of information and understanding required for specifying the agents in the model; therefore data requirements of the traditional sort may be minimal.

Once an individual based model is running, however, it generates large amounts of artificial data as output. For example it can generate output on the sequence of actions taken by each marine farmer agent leading to the establishment — or not — of an aquaculture operation at a particular site. These model generated histories of individual agents and their actions can be aggregated and analysed statistically to yield patterns of behaviour on the part of individuals in various contingent circumstances, as well as outcomes in terms of patterns of marine farm locations under various regulatory options. One of the strengths of this modeling approach is that it generates complex results mirroring the rich complexity of the real system. This is important since the actual behaviour of the real system, as well as the emergence of the problems that are of concern to managers, is the result of the complexity. In contrast, a statistical approach eliminates the richness and complexity by reducing it to a few summary measures like the mean and standard deviation. In doing so it loses the essential nature of the system.

\section{Conclusion}

The research presented here has confirmed the importance of a number of variables identified in the literature as significant for choosing aquaculture sites. However, it has also highlighted variations between different types and groups of marine farmers and the growing importance of community conflicts and planning approaches in determining the spatial expression of marine farming. Planning approaches that provide potential site seekers with flexibility to develop aquaculture in harmony with 
the environment enable expansion of the industry in a wide variety of spatial forms and places. However, the seemingly contrary response of the industry and community to such enabling approaches and the preference for more modernist, restrictive and prescriptive planning strategies suggests the need to better understand the dynamics inherent in the relationships between individuals and their environment if ex ante integrated impact assessment is to be able to aid policy makers and planners. The model conceptualised here suggests the need for managers in the New Zealand context and perhaps in similar international contexts to implement research strategies that provide data and models within an overall linked individual based model and GIS framework. However, given the current lack of such data and models the testing of such an approach may be some time distant, at least in the NZ context.

\section{Acknowledgements}

The authors wish to thank Waikato University's Assoc Prof Lex Chalmers for facilitating the research.

\section{References}

[1]Pascual P. Avoiding tragedies of the commons through integrated impact assessments. Water Resource Management 2007; 21: 2005- 2013.

[2] Van Kouwen F, Dieprink C., Schot P, Wassen N. Applicability of decision support systems for integrated coastal zone management. Coastal Management 2008; 36: 1934.

[3] Waitangi Tribunal. Ahu moana: The aquaculture and marine farming report (Wai 953). Wellington: Waitangi Tribunal; 2003.

[4] Rennie HG. A geography of marine farming rights in New Zealand: Some rubbings of patterns on the face of the sea. PhD dissertation, Hamilton, NZ: University of Waikato; 2002.

[5] Rennie $\mathrm{H}$. A brief history of the last 40 years of marine aquaculture planning in New Zealand. In CL Miller and MM Roche (Eds) Past matters. Heritage, history and the built environment. Palmerston North: Massey University; 2006: 429-441.

[6] Rennie HG. New Zealand mariculture: Unfairly challenged? In DL VanderZwaag and G Chao (Eds) Aquaculture law and policy: Towards principled access and operations. London: Routledge; 2006: 504-523.

[7] Rennie HG. The coastal environment. In PA Memon and HC Perkins (Eds) Environmental Planning in New Zealand. Palmerston North, NZ: Dunmore Press; 1993: $150-168$.

[8] Bess R, Rallapudi R. Spatial conflicts in New Zealand fisheries: The rights of fishers and protection of the marine environment. Marine Policy 2007; 31 719-729. 
[9] Rennie HG. Coastal fisheries and marine planning in transition. In PA Memon and H Perkins (Eds) Environmental Planning \& Management in New Zealand. Palmerston North, NZ: Dunmore Press Ltd.; 2000: 215-222.

[10] European Commission. Impact assessment guidelines Brussels: EC 2006; SEC(2005) vol. 791.

[11] Iversen ES. Farming the edge of the sea. London: Fishing News (Books) Ltd.; 1968.

[12] Iversen ES. Living marine resources: Their utilization and management. New York: Chapman \& Hall; 1996.

[13] Ibrekk HO, Kryvi H, Elvestad S. Nationwide assessment of the suitability of the Norwegian coastal zone and rivers for aquaculture (LENKA). Coastal Management 1993; $21: 53-73$.

[14] Milne PH. Fish and shellfish farming in coastal waters. London: Fishing News (Books) Ltd; 1972.

[15] Edwards DJ. Salmon and trout farming in Norway. Farnham, Surrey: Fishing News Books Limited; 1978.

[16] Coull JR. Fish farming in the Highlands and Islands: Boom industry of the 1980s. Scottish Geographical Magazine 1988; 104(1): 4-13.

[17] Barnabé G (Ed.). Aquaculture: Biology and ecology of cultured species. New York: Ellis Horwood; 1994.

[18] Truscott SJ. Capability studies finfish and shellfish aquaculture as a prerequisite to coastal planning. In PG Wells and PJ Ricketts (Eds) Coastal zone Canada '94, cooperation in the coastal zone: Conference proceedings 4. Halifax, Nova Scotia: Coastal Zone Canada Association; 1994: 1611-1629.

[19] Burbridge PR, Burbridge V. Review of Scottish coastal issues. Edinburgh: The Scottish Office; 1994.

[20] Boghen AD (Ed). Cold-water aquaculture in Atlantic Canada, second edition. Moncton: The Canadian Institute for Research on Regional Development; 1995.

[21] Nash CE. Employment and Manpower in Aquaculture: A Background Review. Rome: FAO; 1992.

[22] Nash CE. Aquaculture Sector Planning and Management. Oxford: Fishing News Books; 1995.

[23] Rosenthal H, Allen JH, Helm MM, McInerney-Northcott M. Aquaculture technology: Its application, development, and transfer. In AD Boghen (Ed) Coldwater aquaculture in Atlantic Canada, second edition. Moncton: The Canadian Institute for Research on Regional Development; 1995: 393-450. 
[24] Rosenthal H, Scarratt DJ, McInerney-Northcott $M$. Aquaculture and the environment. In AD Boghen (Ed) Cold-water aquaculture in Atlantic Canada, second edition. Moncton: The Canadian Institute for Research on Regional Development; 1995; 451-500.

[25] Anutha K, O'Sullivan D (Eds). Aquaculture and Coastal Zone Management in Australia and New Zealand: A New Framework for Resource Allocation. Hobart: Turtle Press; 1994.

[26] Anutha K. Aquaculture in Tasmania. In Anutha K, O'Sullivan D (Eds). Aquaculture and Coastal Zone Management in Australia and New Zealand: A New Framework for Resource Allocation. Hobart: Turtle Press; 1994:16-23.

[27] Anutha K. Conclusion. In Anutha K, O'Sullivan D (Eds). Aquaculture and Coastal Zone Management in Australia and New Zealand: A New Framework for Resource Allocation. Hobart: Turtle Press; 1994: 53.

[28] Anutha K. Integrated coastal zone management - An emerging framework for successful aquaculture development. In Anutha K, O'Sullivan D (Eds). Aquaculture and Coastal Zone Management in Australia and New Zealand: A New Framework for Resource Allocation. Hobart: Turtle Press; 1994: 54-61.

[29] Anutha K, Johnson D. Aquaculture planning and coastal management in Tasmania. Ocean and Coastal Management 1996; 33(1-3): 167-192.

[30] Bailey C, Jentoft S, Sinclair P. Social science contributions to aquacultural development. In C Bailey, S Jentoft, and P Sinclair (Eds) Aquacultural development: Social dimensions of an emerging industry. Boulder: Westview Press; 1996: 3-20.

[31] Bardach JE, Ryther JH, McLarney WO. Aquaculture: The Farming and Husbandry of Freshwater and Marine Organisms. New York: Wiley-Interscience 1972.

[32] Barton JR. Environment, sustainability and regulation in commercial aquaculture: The case of Chilean salmonid production. Geoforum 1997; 38(3-4): 313328.

[33] Barton JR. Salmon aquaculture and Chile's 'export-led' economy. Norsk Geografisk Tidsskrift 1998; 52(1): 37-47.

[34] Barton JR, Staniford D. Net deficits and the case for aquacultural geography. Area 1998; 30(2): 145-155.

[35] Bennett RG. Resource use, conflicts and cultural landscape development in the coastal zone. Norsk Geografisk Tidsskrift 1991; 45: 95-105.

[36] Bjorndal T. The Norwegian aquaculture industry: Industrial structure and cost of production. Marine Policy 1988; April: 122-142.

[37] Chua TE. Coastal aquaculture development and the environment: The role of coastal area management. Marine Pollution Bulletin; 1992; 25(1-4): 98-103. 
[38] Lloyd MG, Livingstone LH. Marine fish farming in Scotland: Proprietorial behaviour and the public interest. Journal of Rural Studies 1991; 7(3): 253-263.

[39] Lloyd MG, Livingstone L. Marine fish farming, planning policy and the environment. Scottish Geographical Magazine 1991; 107(1): 52-57.

[40] Phyne JG. The legal context of industrial aquaculture: Property rights, user conflicts and dispute resolution in three jurisdictions. In PG Wells and PJ Ricketts (eds) Coastal Zone Canada '94, Cooperation in the Coastal Zone, V.1 Dartmouth, NS: Coastal Zone Canada Association 1994; 405-418.

[41] Phyne JG. Along the coast and in the State: Aquaculture and politics in Nova Scotia and New Brunswick. In C Bailey, S Jentoft, P Sinclair (Eds) Aquacultural Development: Social Dimensions of an Emerging Industry. Boulder, CO: Westview Press 1996; 69-92.

[42] Phyne JG. Balancing social equity and environmental integrity in Ireland's salmon farming industry. Society and Natural Resources 1996; 9: 281-293.

[43] Phyne J. Biological warfare: Salmon farming, angling tourism and the sea trout dispute in the west of Ireland, 1989-1995. Irish Journal of Sociology 1996; 6: 1-24.

[44] Phyne J. Capitalist aquaculture and the quest for marine tenure in Scotland and Ireland. Studies in Political Economy 1997; 52: 73-109.

[45] Phyne J. Disputed waters: Rural social change and conflicts associated with the Irish salmon farming industry, 1987-1995. Aldershot, UK: Ashgate Publishing Ltd; 1999.

[46] Ruddy M, Varley T. Sea farming and development in North Connemara. In T Varley, TA Boylan, MP Cuddy (Eds) Rural crisis: Perspectives on Irish rural development Galway: University College 1991; 77-102.

[47] Sandberg A, Didriksen J. Aquaculture policy formation in a highly industrialised society. In D MacInnes, S Jentoft, A Davis (eds) Social Research and Public Policy Formation in the Fisheries. Proceedings of an International Working Seminar held at the Institute of Fisheries, University of Tromso, Tromso, Norway, June 16-20, 1986. Halifax: Oceans Institute of Canada 1991; 64-77.

[48] Tiddens A. Aquaculture in America: The role of science, government, and the entrepreneur. Boulder, CO: Westview Press. 1990.

[49] van der Schans JW. Colonizing the coastal frontier: Governing marine salmon farming in Scotland. In C Bailey, S Jentoft, P Sinclair (Eds) Aquacultural Development: Social Dimensions of an Emerging Industry. Boulder, CO: Westview Press 1996; 143-168. 
[50] van Ginkel R. "Plunderers" into planters: Zeeland oystermen and the enclosure of the marine common. In J Boissevain and J Verrips (Eds) Dutch Dilemmas: Anthropologists Look at the Netherlands. Maastricht: Van Gorcum; 1989: 89-105.

[51] van Ginkel R. Farming the edge of the sea. The sustainable development of Dutch mussel fishery. Maritime Anthropological Studies 1990; 3(2): 49-67.

[52] van Ginkel R. 'One drop of luck weighs more than a bucketful of wisdom'. Success and the idiom and ideology of Dutch shellfish planters. Ethnologia Europaea 1994; 24(2): 155-166.

[53] van Ginkel R. A Dutch Sodom and Gomorrah: Degenerates, moralists and authority in Yerseke, 1870-1914. Crime, Law and Social Change 1996; 24: 223-239.

[54] van Ginkel R. The abundant sea and her fates: Texelian oystermen and the marine commons, 1700 to 1932. Comparative Studies in Society and History 1996; 38(2): $218-242$.

[55] van Ginkel R. The political economy of marine resource management: Dutch musselmen, the state and environmentalists. In D Symes (Ed) Northern waters: Management issues and practice. Oxford: Fishing News Books 1998; 227-237.

[56] van Ginkel R. Capturing and culturing the commons. Public-private dynamics in the Dutch oyster and mussel industry. In J Kooiman, M van Vliet, S Jentoft (Eds) Creative Governance. Opportunities for Fisheries in Europe. Aldershot: Ashgate $1999 ; 35-58$.

[57] van Ginkel R. Contextualizing marine resource use: A case from The Netherlands. Journal of Environmental Policy and Planning 1999; 1: 223-233.

[58] Wood L, Anutha K, Peschken A. Aquaculture: Marine farming of Atlantic salmon. Geography 1990; 75(3): 211-221.

[59] Curtin L. Cultivated New Zealand Rock Oyster. Fisheries Technical Report No. 27. Wellington: New Zealand Department of Marine. 1968.

[60] Curtin L. Oyster farming in New Zealand. Fisheries Technical Report No. 72. Wellington: New Zealand Marine Department. 1971.

[61] Greenway JPC. Settlement and growth of a colony of the large green mussel from a pontoon in Te Kouma Harbour, Coromandel. Wellington: New Zealand Marine Department Technical Report 43. 1969.

[62] Jenkins RJ. Mussel cultivation in the Marlborough Sounds (New Zealand). 1st edition. Wellington: David F. Jones Ltd. 1979.

[63] Jenkins RJ. Mussel cultivation in the Marlborough Sounds (New Zealand). Second edition. New Zealand Fishing Industry Board. Wellington. 1985. 
[64] Hickman RW. Management problems in mussel farming. New Zealand Veterinary Journal 1979; 28: 226-230.

[65] Hickman RW. The future of aquaculture in the Australia and New Zealand region. New Zealand Agricultural Science 1979; 13(4): 171-176.

[66] Hickman RW. Marine farming and coastal water use conflicts. In RW Watters (Ed) Geography and Development Policy. Proceedings of Eleventh New Zealand Geography Conference. Wellington: New Zealand Geographical Society 1982; 159161.

[67] Hickman RW. Growth potential and constraints in the New Zealand mussel farming industry. Proceedings of the New Zealand Society of Animal Production 1987; 47: 131-133.

[68] Hickman RW. Farming the green mussel in New Zealand: Current practice and potential. World Aquaculture 1989; 20(4): 20-28.

[69] Hickman RW. Mussel farming in New Zealand; How much more can it grow?, In N De Pauw, E Jaspers, H Ackefors, N Wilkins (eds) Aquaculture - A Biotechnology in Progress. Bredene: European Aquaculture Society. 1989; 321-325.

[70] Hickman RW. Sources of seed for greenshell mussel farming in New Zealand. International Symposium on Mussels, Pontevedra, Spain, 1989.

[71] Hickman RW. Perna canaliculus (Gmelin) in New Zealand. In W Menzel (ed) Estuarine and Marine Bivalve Mollusk Culture. Boca Raton: CRC Press. 1991: 325334.

[72] Johns TG, Hickman RW. A manual for mussel farming in semi-exposed coastal waters; with a report on the mussel research at Te Kaha, Eastern Bay of Plenty, New Zealand, 1977-82. Occasional Publications No. 50 Wellington: New Zealand Ministry of Agriculture and Fisheries 1985.

[73] Todd P, Coates G. Development of salmon farming in New Zealand: Prospects for the future. In MF Beardsell (Ed) AQUANZ '88: A National Conference on Aquaculture, New Zealand Fisheries Occasional Publication No. 4. Wellington: Ministry of Agriculture and Fisheries. 1989, 21-25.

[74] Marshall J. Landlords, leaseholders \& sweat equity: changing property regimes in aquaculture. Marine Policy 2001; 25: 335-352.

[75] Walters BB. Competing use of marine space in a modernizing fishery: salmon farming meets lobster fishing on the Bay of Fundy. The Canadian Geographer 2007; 51(2): 139-159.

[76] Suryanata K, Umemoto KN. Tension at the nexus of the global and local: culture, property, and marine aquaculture in Hawai'i. Environment and Planning A 2003; 35: 199-213. 
[77] Tveteras S. Norwegian salmon aquaculture and sustainability: the relationship between environmental quality and industry growth. Marine Resource Economics 2002; 17:121-132.

[77] Skladany M, Clausen R, Belton B 2007. Offshore aquaculture: The frontier of redefining oceanic property. Society and Natural Resources 2007; 20:169-176.

[79] Rennie HG. Land-based and Marine Aquaculture in Context - The recent past, the present and the proposed future. In S Botterill (Ed) DSL Environmental Handbook. Wellington: Brookers Limited 2004 (Feb); i-24.

[80] Rennie HG. Aquaculture and fish farming: Integrating activities-based planning. In K. Fullerton (Ed) DSL Environmental Handbook Vol. 2 Wellington: Brookers Limited 2005; (March): i-21.

[81] Northland Regional Council. Proposed Plan Change 4. Whangarei: NRC 2007.

[82] Northland Aquaculture Consortium. Submission on Regional Coastal Plan for Northland - Proposed Plan Change 4. 12 February 2007.

[83] Whalen J, Uljee I, White R, Neis B, Engelen G. An Individual Based Model of the Lobster Fishery in St. John Bay, Newfoundland, Canada. Maastricht: Research Institute for Knowledge Systems. 2004.

[84] Berger T, Goodchild M, Janssen MA, Manson SM, Najlis R, Parker D. Methodological considerations for agent-based modeling of land-use and land-cover change. In DC Parker, T Berger, SM Manson (Eds). Agent-based models of land-use and land cover change: Report and review of an International Workshop Irvine, California, USA October 4-7, 2001 LUCC Report Series No. 6. Belgium: LUCC International Project Office. 2001; 7-25.

[85] Epstein J. Generative social science: Studies in agent-based computational modeling. Princeton: Princeton University Press 2007.

[86] Billari F, Fent T, Prskawetz A, Scheffran J (Eds). Agent-based computational modelling: Applications in demography, social, economic and environmental sciences. Heidelberg: Physica-Verlag 2006.

[87] Troitzsch KG. Social science simulation - origins, prospects, purposes. In R Conte, R Hegselmann, P Terna (Eds) Simulating social phenomena. Berlin: Springer. 1997; 41-54.

[88] Bousquet F, Cambier C, Mullon C, Morand P, Quensiere J. Simulating fishermen's society. In N Gilbert, J Doran (Eds) Simulating societies: the computer simulation of social phenomena. London: UCL Press 1994; 143 -163.

[89] Clarke ME, Rose KA, Levine DA, Hargrove WW. Predicting the effect of climate change on Appalachian trout: Combining GIS and individual-based modelling. Ecological Applications 2001; 11(1), 161-178. 
[90] Doran J. Intervening to achieve co-operative ecosystem management: Towards an agent based model. Journal of Artificial Societies and Social Simulation 2001;

4(2): 1-21.

[91] Railsback SF, Harvey BC. Analysis of habitat-selection rules using an individual-based model. Ecology 2002; 83 (7), 1817-1830. 


\begin{tabular}{|c|c|}
\hline Category & Variable \\
\hline \multirow{17}{*}{ 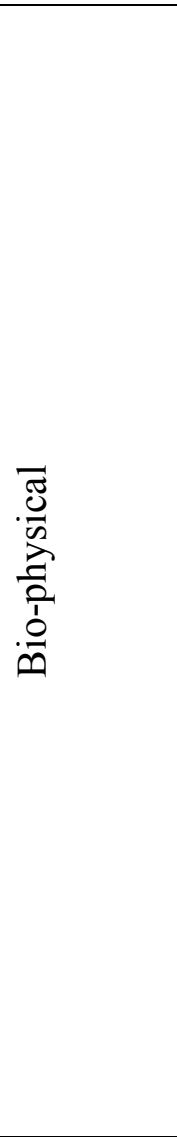 } & Exposure (to wind, waves, air, etc) 'sheltered water' \\
\hline & Temperature \\
\hline & Salinity \\
\hline & Depth (affects, especially, exposure) \\
\hline & Tides and water level fluctuation \\
\hline & Currents and water exchange \\
\hline & Ice \\
\hline & $\begin{array}{l}\text { Geological conditions (e.g., sea-bed composition - hardness, roughness } \\
\text { and chemical composition) }\end{array}$ \\
\hline & Turbidity (suspended sediments) \\
\hline & $\begin{array}{l}\text { Presence or absence of predators (e.g., birds or seals), parasites (e.g., } \\
\text { cestodes) or competitors. }\end{array}$ \\
\hline & Bacterial contamination (e.g., faecal coliform bacteria) \\
\hline & $\begin{array}{l}\text { Depuration (cleansing), a process either naturally occurring or } \\
\text { artificially induced to cleanse shellfish of bacteria that would otherwise } \\
\text { prevent safe consumption) }\end{array}$ \\
\hline & Toxin occurrence (e.g., paralytic shellfish poisoning (PSP)) \\
\hline & Occurrence of phytoplanktonic 'blooms' \\
\hline & $\begin{array}{l}\text { Food availability/prey (e.g., plankton for shellfish), often linked with } \\
\text { water quality. }\end{array}$ \\
\hline & $\begin{array}{l}\text { Species reproductive and growth performance (e.g., length of time to } \\
\text { reach reproductive age, seasonality) }\end{array}$ \\
\hline & Spat/seed/smolt source \\
\hline \multirow{10}{*}{ 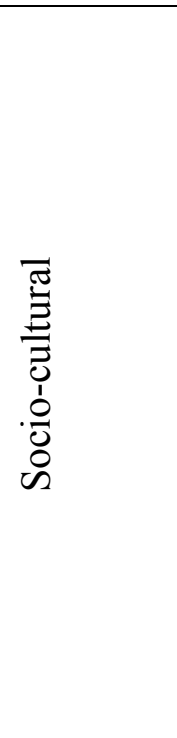 } & Social milieu (e.g., rural communities and industrial versus play-space) \\
\hline & Nature of property rights \\
\hline & Economics and commercial viability \\
\hline & Planning/regulatory regime \\
\hline & $\begin{array}{l}\text { Husbandry/farming practices (e.g., some practices may be more } \\
\text { acceptable in particular communities than others, some may pose lower } \\
\text { risks of importing disease or contaminating the environment than others) }\end{array}$ \\
\hline & $\begin{array}{l}\text { Proximity factors (e.g., to other farms, to shore, market, processor, } \\
\text { home, cheap labour) }\end{array}$ \\
\hline & $\begin{array}{l}\text { Human agency (individuals making things happen while others lose } \\
\text { community trust and support) }\end{array}$ \\
\hline & $\begin{array}{l}\text { Political support/action (including subsidies, education/training and } \\
\text { research) }\end{array}$ \\
\hline & Competition from other users (e.g., ports, navigation, fisheries) \\
\hline & Perceived actual or potential environmental impacts \\
\hline \multicolumn{2}{|c|}{$\begin{array}{l}\text { Drawn from the following publications: [11], [12], [13], [14], [15], [16], [17], [18], [19], } \\
{[20],[21],[22],[23],[24],[25],[26],[27],[28],[29],[30],[31],[32],[33],[34],[35],} \\
{[36],[37],[38],[39],[40],[41],[42],[43],[44],[45],[46],[47],[48],[49],[50],[51],} \\
{[52],[53],[54],[55],[56],[57],[58],[59],[60],[61],[62],[63],[64],[65],[66],[67],} \\
{[68],[69],[70],[71],[72],[73] .}\end{array}$} \\
\hline
\end{tabular}

Table 1 Variables affecting decisions on locations of marine farms (From [4]) 


\begin{tabular}{|c|c|c|c|c|}
\hline & \multicolumn{2}{|c|}{ When (first) site obtained } & \multicolumn{2}{|c|}{ In 2000} \\
\hline Variable & $\begin{array}{l}\text { Single site } \\
\text { owned }\end{array}$ & $\begin{array}{l}\text { 2-10 sites } \\
\text { owned }\end{array}$ & $\begin{array}{l}\text { Single site } \\
\text { owned }\end{array}$ & $\begin{array}{c}2-10 \text { sites } \\
\text { owned }\end{array}$ \\
\hline Water Quality & 2.4 & 1.7 & 1.7 & 1.5 \\
\hline Shelter & 2.7 & 2.1 & 2.4 & 2.1 \\
\hline Close to home & 2.9 & 2.1 & 3.1 & 2.6 \\
\hline Planning restrictions & 2.9 & 2.5 & 1.9 & 1.8 \\
\hline $\begin{array}{l}\text { Opposition/support } \\
\text { from community }\end{array}$ & 3.0 & 2.4 & 2.5 & 1.9 \\
\hline Close to land access & 3.0 & 2.4 & 2.8 & 2.4 \\
\hline $\begin{array}{l}\text { Opposition/support } \\
\text { from iwi/hapu }\end{array}$ & 3.3 & 2.6 & 2.3 & 1.9 \\
\hline $\begin{array}{l}\text { Support/encouragement } \\
\text { from Government }\end{array}$ & 3.4 & 2.8 & 2.6 & 2.8 \\
\hline Close to market & 3.5 & 2.6 & 3.4 & 2.5 \\
\hline $\begin{array}{l}\text { Opportunity to employ } \\
\text { local community youth }\end{array}$ & 3.6 & 2.7 & 3.4 & 2.6 \\
\hline $\begin{array}{l}\text { Opposition/support } \\
\text { from commercial } \\
\text { fishers }\end{array}$ & 3.6 & 2.9 & 3.1 & 2.5 \\
\hline Close to spat source & 3.7 & 1.9 & 3.4 & 2.2 \\
\hline $\begin{array}{l}\text { Opposition/support } \\
\text { from recreational users }\end{array}$ & 3.7 & 2.8 & 3.2 & 2.2 \\
\hline $\begin{array}{l}\text { Availability of cheap } \\
\text { labour }\end{array}$ & 4.1 & 2.8 & 3.6 & 2.7 \\
\hline
\end{tabular}

Table 2 Average rating of variables' importance in determining where to buy or establish a marine farm site (From [4]) 


\begin{tabular}{|l|l|l|l|}
\hline \multicolumn{2}{|c|}{ When (first) site obtained } & \multicolumn{2}{c|}{ In 2000 } \\
\hline Single site owned & 2-10 sites owned & Single site owned & \multicolumn{1}{c|}{ 2-10 sites owned } \\
\hline - Water Quality & - Water Quality & - Water Quality & - Water Quality \\
- Shelter & - Close to Spat & - Planning & - Planning Restrictions \\
- Close to Home & Source & Restrictions & - Opposition/support \\
- Planning & - Shelter & - Shelter & from community \\
Restrictions & - Close to Home & & - Opposition/support \\
& & & from iwi/hapu \\
\hline
\end{tabular}

Table 3 Most critical variables for obtaining site (From [4]) 


\begin{tabular}{|c|c|c|c|}
\hline \multicolumn{2}{|c|}{ Original Classification } & \multicolumn{2}{|c|}{2000 classification } \\
\hline \multirow[t]{6}{*}{$\begin{array}{l}\text { Cluster } \\
\text { One }\end{array}$} & $\begin{array}{l}\text { Recreational } \\
\text { fishers/boaters' } \\
\text { support/opposition }\end{array}$ & \multirow[t]{4}{*}{$\begin{array}{l}\text { Community } \\
\text { cluster }\end{array}$} & $\begin{array}{l}\text { Recreational } \\
\text { fishers/boaters' } \\
\text { support/opposition }\end{array}$ \\
\hline & $\begin{array}{l}\text { Commercial fishers' } \\
\text { support/opposition }\end{array}$ & & $\begin{array}{l}\text { Commercial fishers' } \\
\text { support/opposition }\end{array}$ \\
\hline & $\begin{array}{l}\text { Iwi/hapu } \\
\text { support/opposition }\end{array}$ & & $\begin{array}{l}\text { Iwi/hapu } \\
\text { support/opposition }\end{array}$ \\
\hline & Local cheap labour & & $\begin{array}{l}\text { Community } \\
\text { support/opposition }\end{array}$ \\
\hline & $\begin{array}{l}\text { Providing employment } \\
\text { for community youth }\end{array}$ & \multirow{7}{*}{$\begin{array}{l}\text { Economic } \\
\text { cluster }\end{array}$} & Local cheap labour \\
\hline & $\begin{array}{l}\text { Government } \\
\text { support/encouragement }\end{array}$ & & $\begin{array}{l}\text { Providing employment } \\
\text { for community youth }\end{array}$ \\
\hline \multirow[t]{4}{*}{$\begin{array}{l}\text { Cluster } \\
\text { Two }\end{array}$} & $\begin{array}{l}\text { Close to } \\
\text { market/processing/pack- } \\
\text { aging facilities }\end{array}$ & & $\begin{array}{l}\text { Government } \\
\text { support/encouragement }\end{array}$ \\
\hline & $\begin{array}{l}\text { Close to easy landing } \\
\text { access place }\end{array}$ & & $\begin{array}{l}\text { Close to } \\
\text { market/processing/pack- } \\
\text { aging facilities }\end{array}$ \\
\hline & Close to home & & $\begin{array}{l}\text { Close to easy landing } \\
\text { access place }\end{array}$ \\
\hline & Close to spat/smolt source & & Close to home \\
\hline \multirow{4}{*}{$\begin{array}{l}\text { Cluster } \\
\text { Three }\end{array}$} & Water quality & & $\begin{array}{l}\text { Close to spat/smolt } \\
\text { source }\end{array}$ \\
\hline & Shelter & \multirow{3}{*}{$\begin{array}{l}\text { Fundamentals } \\
\text { cluster }\end{array}$} & Water quality \\
\hline & $\begin{array}{l}\text { Community } \\
\text { support/opposition }\end{array}$ & & Shelter \\
\hline & Planning restrictions & & Planning restrictions \\
\hline
\end{tabular}

Table 4 Clustering of similar variables that affected decisions on farm sites (From [4]) 


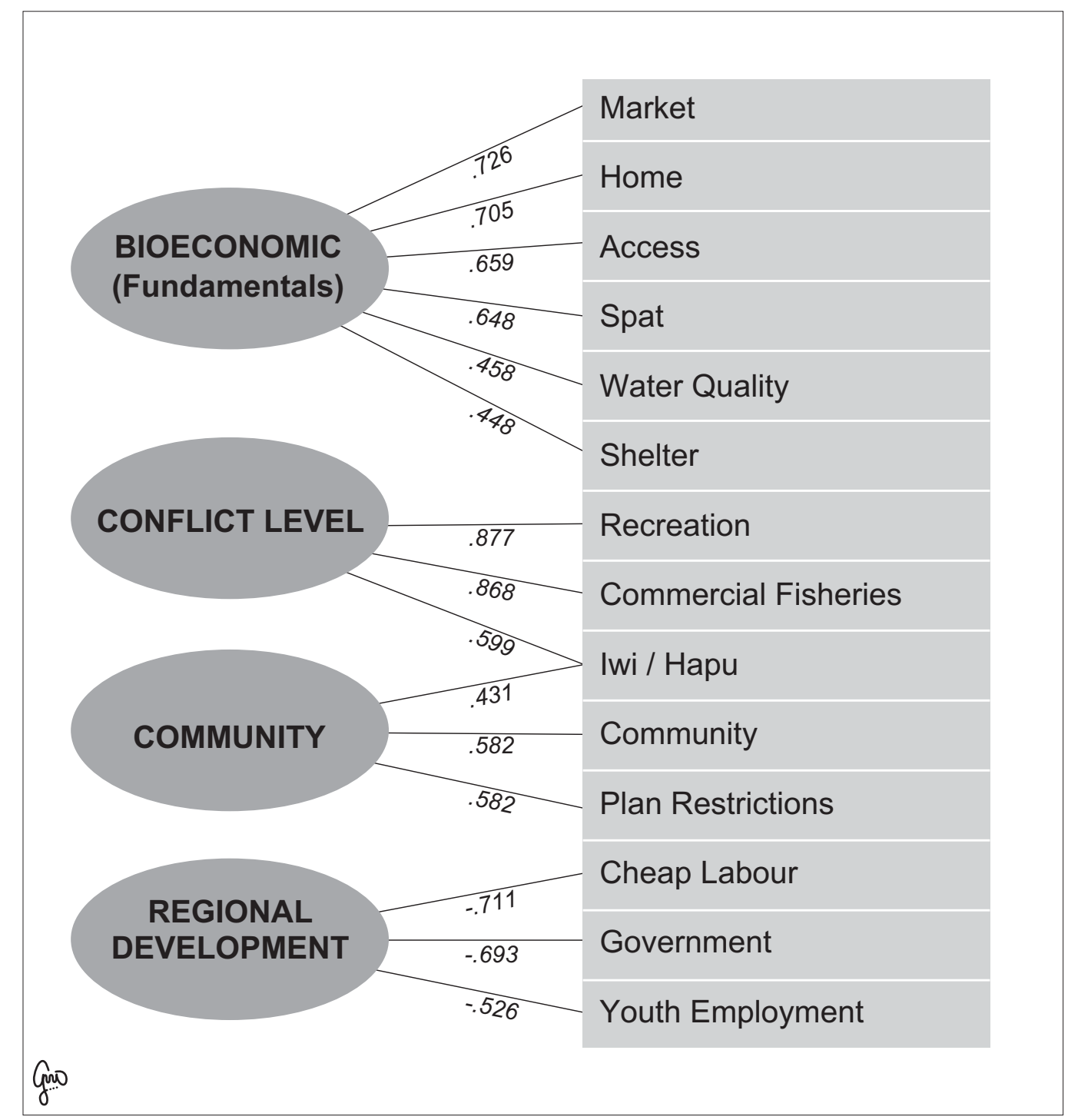

Figure 1 Factors influencing importance of locational variables in 2000 (From [4]) 


\begin{tabular}{|l|c|c|c|c|}
\hline & \multicolumn{2}{|c|}{ When (first) site bought } & \multicolumn{2}{c|}{ In 2000 } \\
\hline $\begin{array}{l}\text { Variable- } \\
\text { Desirability of } \\
\text { site being near: }\end{array}$ & $\begin{array}{c}\text { Single site } \\
\text { owned }\end{array}$ & $\begin{array}{c}2-10 \text { sites } \\
\text { owned }\end{array}$ & $\begin{array}{c}\text { Single site } \\
\text { owned }\end{array}$ & $\begin{array}{c}2-10 \text { sites } \\
\text { owned }\end{array}$ \\
\hline $\begin{array}{l}\text { Isolated or } \\
\text { remote }\end{array}$ & 2.6 & 2.2 & 2.6 & 2.2 \\
\hline $\begin{array}{l}\text { Terrestrial } \\
\text { farms }\end{array}$ & 2.9 & 2.3 & 2.9 & 2.2 \\
\hline $\begin{array}{l}\text { Area of high } \\
\text { natural } \\
\text { character }\end{array}$ & 3.0 & 2.5 & 3.1 & 2.3 \\
\hline $\begin{array}{l}\text { Other marine } \\
\text { farms }\end{array}$ & 3.3 & 2.3 & 3.4 & 2.2 \\
\hline River & 3.5 & 2.2 & 3.7 & 2.0 \\
\hline Forestry & 3.6 & 2.4 & 3.7 & 2.3 \\
\hline Urban area & 3.9 & 2.4 & 4.0 & 2.3 \\
\hline Key: 1= Very Desirable, $2=$ Desirable, $3=$ Neither Desirable Nor Undesirable, \\
$4=$ Undesirable, 5= Very Undesirable
\end{tabular}

Table 5 Average rating of desirability of variables for site selection (From [4]) 


\begin{tabular}{|l|l|l|l|}
\hline \multicolumn{2}{|c|}{ When (first) site obtained } & \multicolumn{2}{c|}{ In 2000 } \\
\hline Single site owned & 2-10 sites owned & Single site owned & 2-10 sites owned \\
\hline - Isolated/Remote & - Isolated/Remote & - Isolated/Remote & - River \\
- Near Terrestrial & - Near Terrestrial & - Near Terrestrial & - Isolated/Remote \\
Farms & Farms & Farms & - Near Terrestrial \\
& - Near river & & Farms \\
& & & - Near Other \\
& & & Marine Farms \\
\hline
\end{tabular}

Table 6 Most desirable site characteristics (i.e., score at least less than 3) (From [4]) 


\begin{tabular}{|l|l|l|l|}
\hline \multicolumn{2}{|c|}{ When (first) site obtained } & \multicolumn{2}{c|}{ In 2000 } \\
\hline Single site owned & 2-10 sites owned* & \multicolumn{1}{|c|}{ Single site owned } & 2-10 sites owned* \\
\hline - Near Urban Area & Near Area of High & - Near Urban Area & - Near Area of \\
- Near Forestry & Natural Character & - Near Forestry & High Natural \\
- Near River & - Near River & - Nearacter Urban Area \\
& & - Near Forestry \\
\hline $\begin{array}{l}* \\
\text { None of the characteristics was scored as undesirable. The ones listed are the lowest scoring of the } \\
\text { desirable characteristics. }\end{array}$ \\
\hline
\end{tabular}

Table 7 Least desirable site characteristics (i.e., score at least more than 3) (From [4]) 


\begin{tabular}{|c|c|c|c|c|c|}
\hline Era & Period & $\begin{array}{l}\text { Approach to } \\
\text { plans }\end{array}$ & \begin{tabular}{|l} 
Rule \\
Tendency
\end{tabular} & Political ideology & $\begin{array}{l}\text { Signature } \\
\text { pattern }\end{array}$ \\
\hline Pre-modern & $\begin{array}{l}1866-1964 \\
\text { (Oyster Fishing Act } \\
1866 \text { ) }\end{array}$ & Exploratory & None & $\begin{array}{l}\text { State directed } \\
\text { development }\end{array}$ & $\begin{array}{l}\text { Sporadic, } \\
\text { scattered } \\
\text { separate }\end{array}$ \\
\hline $\begin{array}{l}\text { Proto- } \\
\text { modern }\end{array}$ & $\begin{array}{l}\text { 1964-1971 } \\
\text { (Rock Oyster Act } \\
\text { 1964, Marine Farming } \\
\text { Act 1968) }\end{array}$ & $\begin{array}{l}\text { Development/ } \\
\text { Exploratory- } \\
\text { Restrictive }\end{array}$ & None & $\begin{array}{l}\text { State directed } \\
\text { development }\end{array}$ & $\begin{array}{l}\text { Sporadic, } \\
\text { some } \\
\text { concentration }\end{array}$ \\
\hline Modern & $\begin{array}{l}\text { 1971-1991 } \\
\text { (Marine Farming Act } \\
\text { 1971) }\end{array}$ & Restrictive & Prohibitive & $\begin{array}{l}\text { Indicative } \\
\text { planning by state, } \\
\text { but tensions with } \\
\text { local government, } \\
\text { which lessened } \\
\text { from } 1984 \text { when } \\
\text { neo-liberalism was } \\
\text { adopted }\end{array}$ & Concentration \\
\hline Transitional & $\begin{array}{l}\text { 1991-2002 } \\
\text { (Resource } \\
\text { Management Act } \\
\text { 1991) }\end{array}$ & Enabling & Discretionary & $\begin{array}{l}\text { Neo-liberal, keep } \\
\text { state out, devolve } \\
\text { decisions to the } \\
\text { affected } \\
\text { community }\end{array}$ & $\begin{array}{l}\text { Sporadic, } \\
\text { scattered, } \\
\text { diverse, } \\
\text { showing } \\
\text { examples of } \\
\text { all types }\end{array}$ \\
\hline$?$ & $\begin{array}{l}2002 \\
\text { (Resource } \\
\text { Management } \\
\text { (Aquaculture } \\
\text { Moratorium) } \\
\text { Amendment Act } \\
\text { 2002) } \\
\end{array}$ & Restrictive & Prohibitive & $\begin{array}{l}\text { Neo-liberal, but } \\
\text { with central state } \\
\text { direction }\end{array}$ & Concentration \\
\hline
\end{tabular}

Table 8 Characteristic signature patterns under different regulatory era and planning approaches (from [4], p.347) 


\begin{tabular}{|l|l|l|l|l|}
\hline & $\begin{array}{l}\text { Approach to } \\
\text { plan change }\end{array}$ & $\begin{array}{l}\text { Rule } \\
\text { tendency }\end{array}$ & Political ideology & Signature pattern \\
\hline $\begin{array}{l}\text { Council } \\
\text { Initiated } \\
\text { Plan } \\
\text { (CIPC) }\end{array}$ & Restrictive & Prohibitive & $\begin{array}{l}\text { Regionally } \\
\text { collaborative } \\
\text { directed } \\
\text { development }\end{array}$ & $\begin{array}{l}\text { Large, } \\
\text { concentrated } \\
\text { block }\end{array}$ \\
\hline $\begin{array}{l}\text { Uninvited } \\
\text { Private Plan } \\
\text { Change } \\
\text { (UPPC) }\end{array}$ & Exploratory & Discretionary & $\begin{array}{l}\text { Enabling possibly } \\
\text { unintended } \\
\text { explorations of new } \\
\text { species and } \\
\text { purposes of limited } \\
\text { competitive interest }\end{array}$ & $\begin{array}{l}\text { Limited, } \\
\text { sporadic, diverse, } \\
\text { scattered, small } \\
\text { scale innovative } \\
\text { and/or 'special' }\end{array}$ \\
\hline $\begin{array}{l}\text { Invited } \\
\text { Private Plan } \\
\begin{array}{l}\text { Change } \\
\text { (IPPC) }\end{array}\end{array}$ & Enabling & Discretionary & $\begin{array}{l}\text { Devolve decisions } \\
\text { to industry }\end{array}$ & $\begin{array}{l}\text { Sporadic, } \\
\text { scattered, } \\
\text { diverse, showing } \\
\text { examples of all } \\
\text { types }\end{array}$ \\
\hline $\begin{array}{l}\text { No Plan } \\
\text { change }\end{array}$ & Prohibitive & Restrictive & $\begin{array}{l}\text { Aquaculture of } \\
\text { limited future }\end{array}$ & $\begin{array}{l}\text { Deemed farms } \\
\text { possibly slowly } \\
\text { declining in } \\
\text { scale. }\end{array}$ \\
\hline
\end{tabular}

Table 9 Probable post-moratorium planning regime signature patterns 